\title{
Development of the Russian-EU cooperation against organized crime and terrorism
}

\author{
Anna Y. Marchenko ${ }^{1, *}$ \\ ${ }^{1}$ MGIMO University, 119454, 76 Vernadsky ave., Moscow, Russia
}

\begin{abstract}
This article is dedicated to the question of the development of the Russian-EU cooperation against organized crime and terrorism. The paper analyzes the EU-Russia Partnership and Cooperation Agreement in general and in the context of abovementioned spheres, as well as the Agreement on cooperation between the European Police Office and the Russian Federation. Moreover, the article examines other forms of cooperation and the EU/Russia Road Map on the common space of freedom, security and justice. Finally, this article reveals the problems and perspectives of the Russian-EU cooperation in the fields of organized crime and terrorism.
\end{abstract}

The history of relations between contemporary Russia and the European Union is about thirty years. It is generally accepted that the signing on June 25, 1988 of the Joint Declaration on the Establishment of Official Relations between the Council for Mutual Economic Assistance (CMEA) [1] and the European Economic Community (EEC) [2] first established at the intergovernmental level the cooperation of the USSR and the European Communities [3]. A year later, in December 1989, the USSR, the EEC and Euratom signed the Agreement on Trade, Commercial and Economic Cooperation [4]. This Agreement was the normative and legal basis for Russia's cooperation as the legal successor of the USSR with the EC (European Communities) in the next 8 years, until the 1997 Partnership and Cooperation Agreement (PCA) came into effect [5].

S. M. Yun, assessing the model of "partnership and cooperation" between Russia and the EC based on the Partnership and Cooperation Agreement suggests that "as one of the main guidelines for Russian diplomacy in the negotiations with the EC on the PCA model was the agreement on the European Economic Area (EEA) signed on May 02, 1992 between the EC countries and seven members of the European Free Trade Association (EFTA). Its participants from the EFTA countries eventually became Norway, Iceland, Liechtenstein who did not want to join the EC. On the basis of the EEA Agreement the EFTA countries were broadly integrated into the EC internal market on the basis of the Four Freedoms concept of (freedom of movement of goods, services, labour forces and capitals) in exchange for the transfer of EC standards to the national legislation of the EFTA countries (otherwise called the "horizontal approach"). Given the differences in the approaches between the EC and the Russian Federation the Russian diplomacy has put forward the concept of a step-by-step rapprochement with the EC according to which the

* Corresponding author: lady-g-unit@list.ru 
political dialogue and economic interaction based on the GATT norms should first develop, in its turn, the final goal could be a transition in relations with the EC on the Four Freedoms principle" [6].

By reason of the protracted negotiations, Russia and the EC signed the Agreement only on June 24, 1994. Its essential difference from earlier similar agreements signed by the EC was that the PCA did not prescribe, but briefly mentioned the possibility of the RussianEuropean integration in the future within the framework of three of the Four Freedoms of a single market: trade in goods, trade in services and trade in capital (articles 1, 3 of the PCA).

At the same time, the PCA is legitimately recognized as an obligatory treaty of an international legal nature that forms a number of interrelated political, legal and moral obligations, called upon to play the role of guiding principles in the relations between Russia and Europe. L.O. Igumnova emphasizes that Moscow's acceptance of these commitments was completely voluntary, given the Russian reality of the 1990s. [7].

The agreement came into force in 1997 for an initial period of 10 years. Since 2007, it has been annually renewed remaining the legal basis for bilateral relations. Negotiations on the development of a new agreement are still ongoing.

In the domestic legal literature it is noted that the PCA is a solid legal framework (base) designed to bring Russia closer to European legal, economic and trade standards [8]. It is no coincidence that links to common values have already been included in the preamble of the agreement. The parties stated that they take into account "the importance of historical ties existing between Russia and the Community and its member states and the values common for them" and "are convinced of the paramount importance of the rule of law and respect for human rights, especially the rights of minorities, creation of a multi-party system with free and democratic elections and economic liberalization ... "(PCA, Preamble). In Art. 1 of the Agreement it is confirmed that the objectives of the partnership between Russia and the EC are "strengthening political and economic freedoms" and "supporting Russia's efforts to strengthen its democracy" (Section I, Article 1). Recognizing the importance of the cited provisions of the PCA, it is still worth agreeing that the main article that establishes the primacy of common values as the basis of partnership is Art. 2, which reads: "Respect for democratic principles and human rights, as defined in particular in the Helsinki Final Act and in the Charter of Paris for a New Europe, is the basis of the domestic and foreign policies of the Parties and constitutes an essential element of partnership and this Agreement" (Sect. I, Art. 2) [9].

On the basis of the PCA, it was supposed to build cooperation in the sphere of security, justice and internal affairs. In truth, this area of cooperation did not have a priority character. The norm of Art. 84, Sect. VIII of the PCA only provided that the parties will cooperate in counteracting illegal immigration, drug trafficking, economic crimes, counterfeiting, illegal transactions with various types of goods. However, in the subsequent years of the document's validity, the Agreements on the simplification of visa issuance, on readmission (both in 2006), on the protection of classified information (2010), the work on the transition to a visa-free regime between Russia and the EC has been started, the interaction of Russian specialized agencies with Europol and Eurojust has been established, regular contacts on combating terrorism and countering illegal trafficking in narcotic and psychotropic drugs have been made.

The most significant event took place on November 06, 2003 when in order to establish the procedures for interaction between the law enforcement agencies of the Russian Federation and the European Union member states in countering terrorism, organized crime, illegal money laundering, drug trafficking during the Russia-EU summit in Rome (Italy), the parties entered into an Agreement on cooperation between the European Police Office and the Russian Federation [10]. 
Within the framework of the Agreement, cooperation in combating transnational crime and terrorism is conducted against eight categories of crimes: 1) against human life and health; 2) terrorist acts and their financing; 3) illegal traffic in narcotic drugs and psychotropic substances; 4) smuggling of values of cultural importance; 5) illegal circulation of arms, ammunition, explosive, poisonous substances, nuclear and radioactive materials; 6) crimes against property, including fraud, theft, etc.; 7) legalization (laundering) of proceeds from crime; 8) organization of illegal migration, slave trade and exploitation of prostitution by third parties. According to these directions, the experience and practical information, normative-legal acts and methodological tools are exchanged. Joint seminars, study visits and consultations are organized [11].

The Ministry of Internal Affairs, the Federal Security Service, the Federal Customs Service and Federal Financial Monitoring Service of the Russian Federation (Rosfinmonitoring) are responsible for the implementation of the Agreement from the Russian part. The structure of the Ministry of Internal Affairs of Russia has a special unit responsible for information exchange and coordination of joint actions with Europol - the Russian National Contact Point for Interaction with Europol (RNCP). Moreover, it is noted that the joint activity of these agencies is only one of the many directions in the system of counteraction to various forms of crime and ensuring public order (security) [12].

In addition, Russian experts regularly provide Europol with the information materials on organized crime and international terrorism which the European Office uses in its annual reports on the situation in the EC.

Along with the forms of cooperation, the Russian delegation gradually participated in the annual meetings of the heads of the national contact points of third countries on interaction with Europol and conferences of heads of law enforcement agencies of the EC member states and Europol partner countries.

In turn, European experts are regularly invited to attend seminars and conferences organized in Russia on combating terrorism and organized crime, counterfeiting, crimes in the field of intellectual property, cybercrime, illicit drug trafficking, and witness protection.

However, despite regular contacts, the practice of interaction began to demonstrate that the existing legal framework for cooperation requires renewal. For several years, the issue of establishing operational cooperation with Europol was considered on a multilateral basis. In particular, since October 2010, the negotiations on the conclusion of a new agreement which was to provide for the possibility of exchanging operational information and personal data, as well as joint operational activities began. The implementation of these plans was aimed not only at the maintaining the dynamics of cooperation development, but also bringing it to a new level.

It is worth supporting the Yu. A. Ryabov's view that the ratification by the Russian Federation of the Council of Europe Convention on the Protection of Individuals with the Automated Processing of Personal Data of 1981, as well as the adoption in 2006 of federal laws "On Personal Data" and "On Information, Information Technologies and Information Protection". This allowed for an equal dialogue on the conclusion of a full-fledged operational agreement with Europol [13].

Special attention should be given to the Road Map of the common space of freedom, security and justice concluded by the European Union with Russia in 2006. This document shows a certain synthesis of the interests of the two parties. On the one hand, Brussels promoted the principles embodied in the final text of the document on equality of partners, adherence to the common values of a democratic and rule-of-law state, their application in an independent judicial system, respect for human rights, mutual respect and compliance with international law. In turn, Moscow considered the principle of equality in the relations of the parties to be the key principle since it provided at least a theoretical opportunity to reduce the tone in the leading role of Brussels. 
The Road Map covered three large blocks of interaction: freedom, security and justice. In particular, the counteraction to terrorism and all forms of organized crime was declared as the main goal of the second block, security. Yu. A. Ryabov is right when he notes that it is "there is a certain balance of interests in which neither party is given the status of 'pure petitioner' in this block". This is confirmed, for example, by the absence of provisions on the need to develop a definition of terrorism and the harmonization of a single list of terrorist organizations which can nullify practical measures to counter this threat" [14].

Subsequently, a conflict in the east of Ukraine and the entry of Crimea into the Russian Federation had a serious impact on bilateral political dialogue in 2014. As a result of these and other subsequent events, some cooperation mechanisms were "temporarily frozen".

In general, meanwhile the potential of cooperation between Russia and the EC in the fight against organized crime and terrorism remains underutilized. The institutional framework for dialogue that has been formed to date is an obstacle to further development, for example, until now, there is no specialized subcommittee in the field of justice and home affairs in the structure of joint bodies established in accordance with the Partnership and Cooperation Agreement. At the same time, despite the existing negative rhetoric, it is increasingly possible to hear opinions that it is the need to consolidate joint efforts in countering terrorist threats that can become a sphere from which rapprochement and relations can begin [15]. As a graphic illustration of this, we can cite the statement of the Foreign Ministers of the EU member states of June 19, 2017 on the importance of cooperation in combating terrorism with a number of international organizations and countries, including Russia [16].

\section{Notes}

1. The Council for Mutual Economic Assistance (CMEA) was an intergovernmental economic organization established in 1949 in accordance with the decision of the economic meeting of the representatives of the USSR, Bulgaria, Hungary, Poland, Romania and Czechoslovakia. The Council has been active since 1960. Formally it was dissolved in 1991.

2. The European Economic Community, after the entry into force of the Maastricht Treaty in 1993, became known as the Economic Community (EC); and since December 01, 2009 (with the entry into force of the Lisbon Treaty), it became the European Union.

3. The Council for Mutual Economic Assistance (CMEA) was an intergovernmental economic organization established in 1949 in accordance with the decision of the economic meeting of the representatives of the USSR, Bulgaria, Hungary, Poland, Romania and Czechoslovakia. The Council has been active since 1960. Formally it was dissolved in 1991.

4. The European Economic Community, after the entry into force of the Maastricht Treaty in 1993, became known as the Economic Community (EC); and since December 01, 2009 (with the entry into force of the Lisbon Treaty), it became the European Union.

\section{References}

5. N. S. Semenova, Legal framework for economic and social regulation of the EU: teaching and methodical manual, 537-538 (VolGU, Volgograd, 2010) 
6. ConsultantPlus, Agreement between the USSR and the European Economic Community and the European Atomic Energy Community on Trade and Commercial and Economic Cooperation (concluded in Brussels on 18/12/1989) (2018)

7. International Treaties Bulletin, 8, 3-74 (1998)

8. S. M. Yun, Russia and the European Union: Textbook (Tomsk University Publishing House, Tomsk, 2014)

9. L. O. Igumnova, Normative Aspects of Relations Between Russia and the EU. In S. M. Yun (Ed.), Russia and the European Union: Textbook (Tomsk University Publishing House, Tomsk, 2014)

10. S. I. Vodorezov, Bulletin of Bryansk University, 2 (2009)

11. L. O. Igumnova, Russia and the European Union: Textbook (Tomsk University Publishing House, Tomsk, 2014)

12. International Treaties Bulletin, 3, 58-62 (2004)

13. I. K. Nikishkin, Administrative Law and Process, 10 (2013)

14. V. S. Grishin, Actual problems of law: Proceedings of the V International Scientific Conference (Moscow, December 2016) (Buki-Vedi, Moscow, 2016)

15. Yu. A. Ryabov, Formation of the Foreign Policy Dimension for the Space of Freedom, Security and Justice of the European Union: Thesis ... PhD in Polit. Sciences (St Petersburg, 2014)

16. ibid

17. I. A. Emelina, Actual Problems of Modern International Relations, 4 (2016)

18. V. Dobrovolsky, The importance of interaction with Russia in the fight against terrorism was declared in the EU (https://ria.ru/world/20170619/1496834021.html, 2018). 